\title{
Modern problems of phosphorus in farming agriculture and ways of their solution
}

B. Nosko,

Academician of NAAS, Doctor of Agricultural Sciences

National Scientific Center "Institute for Soil Science and Agrochemistry

Research named after O.N. Sokolovsky"

The purpose. To determine the basic regularities of conversion of phosphatic fund of soils in modern conditions of farming agriculture. Methods. Generalization of results of long-term (1969 - 2013) probes in field experiments on typical and degraded chernozem, and also of the published materials of laboratory of methodical control of agrochemical service (now - department of agrochemistry). Results. Regularities of dynamics of different forms of soil phosphates (gross, organic, mobile forms, fractional composition) depending on doses and methods of application of organic and mineral fertilizers, balance of phosphorus in crop rotation are justified. Features of accumulation of residual forms of phosphate and their influence upon formation of agrogenic profile of soils and their fertility are fixed. Conclusions. Dynamics of balance of phosphorus in farming agriculture of Ukraine and its close connection with the content of mobile phosphorus in arable layer of soils, accumulation of residual phosphates in the period from 1970 to 1990 has been determined. For improving scarce balance of phosphorus which was observed in $1995-2015$ it is recommended to use local source of raw materials: phosphorite meal, peat, sapropel, green manure crops, plant residues of crops and to implement the following agrotechnical methods: local fertilization and acid soils liming.

Key words: phosphorus, balance of phosphorus, residual phosphates, soil fertility.

The problem of phosphorus in agriculture around the world is constantly because of the insufficient soil availability of its compounds to plants and the need to constantly use phosphate fertilizers to reduce the deficit balance.

Unlike carbon, oxygen, nitrogen and sulfur, biogeochemistry of phosphorus almost entirely is associated with living matter (V.A. Kovda, 1985), that is phosphorus is an absolutely biophil element and its content in the soil depends on the amount of organic matter. Gross content of phosphorus in humus profile is the result of its biological transfer from soil rock, which in turn has a varying number of elements depending on the mineralogical composition.

Stocks of gross phosphorus in the meter layer of soil of Ukraine range from 2,5-3,8 t/ha in sod-podzolic sandy loam and sandy soils of Polissya to 20-23 tha in chernozems typical and chernozems ordinary of Forest - Steppe and Steppe.

Phosphate regime of soils is closely dependent on intensiveness of its agricultural use, which makes both negative and positive effects.

The purpose of the research - to establish the basic laws of transformation of phosphate soil fund under the influence of the most important factors, characteristic of modern agriculture, and justification for actions of its optimization, including balance of phosphorus dynamics of the content in the soils of available phosphates, impact of fertilizers on the content and the degree of availability of phosphate, accumulation of residual phosphates, and the role of agronomic, biological and chemical measures to increase the content in soils phosphates forms digestible by plants.

Research Methodology. There are conducted long-term research (1969-2013) in field experiments on chernozem typical and podzolized heavy loamy on the territory NSC ISSAR Experimental Field "Grakivske" State Enterprise and summarized published materials of Agrochemistry Department. 
Research results. The main source of phosphate nutrition is the most available phosphates of soil solution, but their number in soils of different types does not satisfy fully the needs of plants in this element, especially it is observed in sod-podzolic sandy and loamy soils of Polissya, where there is a high efficiency of phosphate fertilizers.

However, the use of organic and mineral fertilizers during the 60 s of the last century in agriculture of Ukraine (1966-1970) was extremely low: the average per hectare of arable land there were applied $49 \mathrm{~kg} / \mathrm{ha}$ a.m., $14 \mathrm{~kg} / \mathrm{ha} \mathrm{P}_{\mathrm{O}} \mathrm{O}$. Against the background of low standards applying manure (about $4 \mathrm{t} / \mathrm{ha}$ ) applicated into soil fertilizers did not provide the full return of phosphorus, which was alienated with the harvest that consisted of a negative balance of phosphorus in agriculture in general.

But since the 1971-1975 in connection with the intensive development of chemicals, phosphorus balance is positive: already during these five years balance of phosphorus in agriculture in the areas of Polissya and Forest-Steppe is positive, exceeding the annual income of phosphorus, is respectively, 11.7 and $7.3 \mathrm{~kg} \mathrm{P} O$ per ha on arable land, and only in the Steppe zone it remains negative - $2.0 \mathrm{~kg} / \mathrm{ha}$ (Table. 1).

In the next five-year plan, including the 1986-1990, a positive balance of phosphorus increases in all natural areas. Excess phosphorus flow of organic and mineral fertilizers for twenty years (1971-1990) reached $352.5 \mathrm{~kg} / \mathrm{ha}$ in Polissya, Forest-Steppe $267.0 \mathrm{~kg}$ and $199.5 \mathrm{~kg}$ in the Steppe zone, and generally in agriculture of Ukraine reached a positive balance of phosphorus $248 \mathrm{~kg} / \mathrm{ha}$.

Systematic monitoring conducted by the State Agrochemical Service, showed the presence of positive dynamics of content of available phosphates in all natural areas (Table. 2). Under the influence of a significant excess of revenues over their phosphate removal of the harvest crop an average content of available phosphorus increased (compared to the first round of the survey - 1964-1970) in Polissya from 6.3 to 11.8 $\mathrm{mg} \mathrm{P}: \mathrm{O}$; per $100 \mathrm{~g}$ soil in steppe respectively, from 8.1 to 10.6 and in step - from 6.7 to $10.1 \mathrm{mg} \mathrm{P}: \mathrm{O}$; per $100 \mathrm{~g}$ of soil. On average in Ukraine, on an area of about 30-31 million hectares, the average content of available phosphorus increased from 7.1 to $10.6 \mathrm{mg}$ per $100 \mathrm{~g}$ soil. 
1. The dynamics of the total balance of phosphorus in agriculture of Ukraine, $\mathrm{P} \cdot \mathrm{O}_{\mathrm{i}}, \mathrm{kg} / \mathrm{ha}$

\begin{tabular}{|c|c|c|c|c|c|c|c|c|c|c|c|c|c|}
\hline \multirow{2}{*}{$\begin{array}{l}\text { Natural } \\
\text { zone }\end{array}$} & \multicolumn{3}{|c|}{ 1971-1975 } & \multicolumn{3}{|c|}{ 1976-1980 } & \multicolumn{3}{|c|}{ 1981-1985 } & \multicolumn{3}{|c|}{ 1986-1990 } & \multirow{2}{*}{$\begin{array}{l}\text { The total } \\
\text { exceeding } \\
\text { income } 20 \\
\text { years } \\
(1971-1990)\end{array}$} \\
\hline & Income & Removal & Balance & Income & Removal & Balance & Income & Removal & Balance & Income & Removal & Balance & \\
\hline Polissya & 35,5 & 23,8 & 11,7 & 42,4 & 26,8 & 15,6 & 48,8 & 26,5 & 18,3 & 56,1 & 31,2 & 24,9 & 352,5 \\
\hline $\begin{array}{l}\text { Forest- } \\
\text { Steppe }\end{array}$ & 35,0 & 27,7 & 7,3 & 43,2 & 31,2 & 12,0 & 44,4 & 30,0 & 14,4 & 54,5 & 34,8 & 19,7 & 267,0 \\
\hline Steppe & 22,8 & 24,8 & $-2,0$ & 34,6 & 28,0 & 6,6 & 40,4 & 26,2 & 14,2 & 49,8 & 29,9 & 19,19 & 199,5 \\
\hline $\begin{array}{l}\text { Around } \\
\text { Ukraine }\end{array}$ & 29,4 & 25,5 & 3,9 & 39,1 & 29,0 & 10,1 & 42,7 & 27,7 & 15,0 & 52,5 & 31,9 & 20,6 & 248,0 \\
\hline
\end{tabular}


2. Dynamics of available forms of phosphorus in soils on the results of five rounds of agrochemical examination (Handbook...., 1994)

\begin{tabular}{|c|c|c|c|c|c|c|}
\hline \multirow{2}{*}{$\begin{array}{l}\text { Round } \\
\text { of } \\
\text { survey }\end{array}$} & \multirow{2}{*}{$\begin{array}{l}\text { Surveys of } \\
\text { arable land, } \\
\text { thous. ha }\end{array}$} & \multicolumn{4}{|c|}{$\begin{array}{l}\text { Area of soil groups by content } \mathrm{P}_{2} \mathrm{O}_{5} \\
\text { ( } \% \text { from survey) }\end{array}$} & \multirow{2}{*}{$\begin{array}{l}\text { Average content } \\
\mathrm{P}_{2} \mathrm{O}_{5}, \mathrm{mg} / 100 \mathrm{~g} \\
\text { of soil }\end{array}$} \\
\hline & & low & medium & $\begin{array}{l}\text { increas- } \\
\text { ing }\end{array}$ & high & \\
\hline \multicolumn{7}{|l|}{ Polissya } \\
\hline 1 & 4892,8 & 59,2 & 26,1 & 10,1 & 4,5 & 6,3 \\
\hline V & 4431,7 & 18,6 & 31,5 & 25,2 & 24,7 & 11,8 \\
\hline \multicolumn{7}{|c|}{ Forest-Steppe } \\
\hline I & 11058,3 & 22,3 & 52,1 & 20,5 & 5,1 & 8,1 \\
\hline V & 11072,9 & 9,9 & 40,6 & 32,9 & 16,6 & 10,6 \\
\hline \multicolumn{7}{|l|}{ Steppe } \\
\hline I & 14989,9 & 33,5 & 53,1 & 11,3 & 2,1 & 6,7 \\
\hline V & 13872,1 & 7,5 & 48,4 & 29,5 & 14,6 & 10,1 \\
\hline \multicolumn{7}{|c|}{ Around Ukraine } \\
\hline I & 30938,0 & 33,6 & 48,5 & 14,4 & 3,5 & 7,1 \\
\hline V & 29376,7 & 10,0 & 42,39 & 30,1 & 17,0 & 10,6 \\
\hline
\end{tabular}

According to preliminary estimates as a result of the 20 years old positive balance of phosphorus in soils (mostly in the plow layer) there were accumulated between 300 and $500 \mathrm{~kg} \mathrm{P} \mathrm{O}_{\text {; }}$ per hectare so-called "residual" phosphates. Beginning from 1991-1995, Ukraine sharply reduced (at times!) the volume and use of organic fertilizers. Agriculture again returned to the terms of phosphorus balance deficit (in 2015 it amounted to $-12.3 \mathrm{~kg} \mathrm{P}$. ; per hectare (Lisovy M.V., Nikonenko V.M., 2016), there was downward trend of moving content phosphate (Fig. 1).

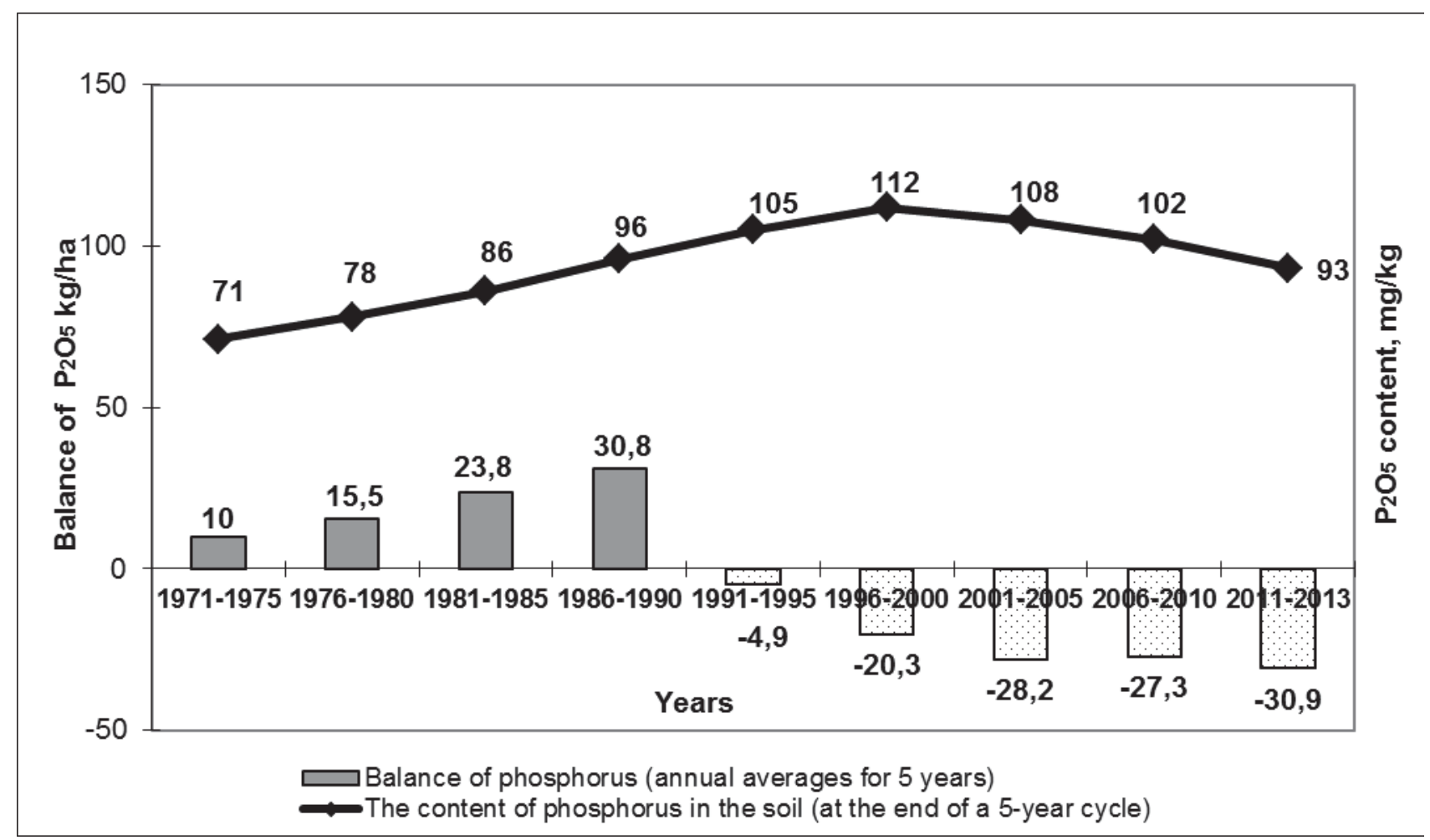

Fig. 1 Dynamics of the average balance of phosphorus and $P, O$ content in soils in agriculture of Ukraine 
According to the "Periodic Report on the state of soil on agricultural lands" (2015) on the results of the 9th round of land survey (2006-2010) more than $53 \%$ of soils are characterized by low and middle $\mathrm{P} ; \mathrm{O}$ content that is less than $10.0 \mathrm{mg}$ per $100 \mathrm{~g}$ soil that does not meet the requirements of most field crops to provide available forms of phosphate and to obtain a high level of yields it is necessarily to applicate mineral phosphate fertilizers.

The results of our scientists and many other studies have shown that applied in the soil phosphate fertilizer quickly absorbed by solid phase that is actually moving in the form of phosphates, typical for this type of soil. However, residual phosphates differ from natural forms much greater availability for power plants.

Available or bioavailable nutrient is one that is present in a pool of ions in the soil and can move to the roots of plants during their growth if the root is close enough (average distance that phosphorus due to diffusion in soil with a high content according to S.A. Barber (1984)) and A.Yu. Kudeyarova (1971) varies depending on the grain size and the degree of humidity, from 0.9 to $2.0 \mathrm{~mm}$ ).

Adsorbed phosphate, which is balanced between the solid and liquid phase, we quickly (within 24 to 48 hours) conventionally called phosphate volume; phosphate, adjusted slowly called fixed phosphorus. Research has established that absorption (adsorption) phosphate from the soil solution defined four stages, which stands for speed chernozem in which 6 days absorbed about $80 \%$ applied phosphates.

Subsequently, the absorption was much slower (B.S. Nosko, I.O. Horolets, 1987). By the absorption of phosphorus from the solution equilibrium in phosphate is broken and moving quickly in solution. It violates balance between moving and stationary forms; as a result, it takes place a very slow transition from fixed pool of phosphate into the available one.

By forecasting the efficiency of phosphorus fertilizer according to soil chemical analysis we must take into account the aftereffect of residual phosphates and duration in time. It will be determined by the speed of transfer residual phosphates in insoluble compounds, as well as the relation between available phosphates (capacity factor) and the degree of availability (intensity factor).

In chernozem typical heavy loamy (research on the territory ISSAR Experimental Field "Grakivske") in the control variant after 30 years of systematic plowing in the plow layer the most intensive changes occur in soil organic phosphates, the number of which decreased from 62.2 to $38.8 \mathrm{mg} \mathrm{P} \mathrm{O}_{\mathrm{i}} / 100 \mathrm{~g}$ soil , due mainly mineralization of humus and reduce the amount of active phosphates - from 35.1 to $23.7 \mathrm{mg} \mathrm{P} \mathrm{O}_{\mathrm{i}} / 100 \mathrm{~g}$ soil, respectively (Table 3).

It must be emphasized almost constant (within allowable error analysis) content of available phosphates (by Chirikov and Olsen) to control variant, which indicates high buffering of chernozem and its ability during extended period to support these indicators in a balanced state, despite the negative balance of phosphorus that reaches $800 \mathrm{~kg} \mathrm{P}$ O per hectare in 30 years of agricultural use of chernozem. 
3. Aftereffect of mineral fertilizers on phosphate fund structure of chernozem typical heavy loamy

\begin{tabular}{|c|c|c|c|c|c|c|c|c|c|c|}
\hline \multirow{3}{*}{ Depth } & \multicolumn{9}{|c|}{ Content of $\mathrm{P}_{2} \mathrm{O}_{5}, \mathrm{mg} / 100 \mathrm{~g}$ soil } & \multirow{3}{*}{$\begin{array}{l}\text { Degree of } \\
\text { availability } \\
\mathrm{P}_{2} \mathrm{O}_{5}, \mathrm{mg} / \mathrm{l}\end{array}$} \\
\hline & \multirow{2}{*}{ gross } & \multirow{2}{*}{ organic } & \multicolumn{2}{|l|}{ available } & \multicolumn{4}{|c|}{ Fractional composition } & \multirow{2}{*}{$\begin{array}{l}\text { Amount of } \\
\text { active } \\
\text { phosphates }\end{array}$} & \\
\hline & & & $\begin{array}{l}\text { by } \\
\text { Chirikov }\end{array}$ & $\begin{array}{l}\text { by } \\
\text { Olsen }\end{array}$ & $\begin{array}{l}\text { loosely } \\
\text { connected }\end{array}$ & Al-P & Fe-P & Ca-P & & \\
\hline 1 & 2 & 3 & 4 & 5 & 6 & 7 & 8 & 9 & 10 & 11 \\
\hline \multicolumn{11}{|c|}{ Fallow, more than 75 years } \\
\hline $0-20$ & 125,0 & 62,2 & 5,0 & 1,6 & 0,13 & 8,7 & 12,9 & 13,4 & 35,1 & 0,06 \\
\hline $20-40$ & 113,4 & 60,0 & 4,7 & 1,1 & 0,07 & 6,1 & 7,0 & 13,1 & 26,2 & 0,03 \\
\hline $40-60$ & 107,7 & 49,1 & carbonates & 0,76 & 0,06 & 5,6 & 3,7 & 15,1 & 24,4 & 0,03 \\
\hline $60-80$ & 103,9 & Not determ. & 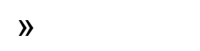 & 0,69 & - & - & - & - & - & 0,03 \\
\hline $80-100$ & 99,8 & $《-»$ & ॥ & 0,63 & - & - & - & - & - & 0,04 \\
\hline \multicolumn{11}{|c|}{ Control (plowing without fertilizers, 30 years) } \\
\hline $0-20$ & 112,0 & 38,8 & 4,7 & 1,3 & 0,19 & 5,6 & 6,0 & 11,9 & 23,7 & 0,04 \\
\hline $20-40$ & 105,0 & 37,5 & 4,6 & 1,2 & 0,15 & 4,8 & 5,0 & 12,8 & 22,7 & 0,03 \\
\hline $40-60$ & 96,3 & 33,1 & carbonates & 0,11 & 0,12 & 4,4 & 4,5 & 15,7 & 24,8 & 0,03 \\
\hline $60-80$ & 92,3 & 32,2 & 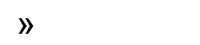 & 1,03 & - & - & - & - & - & 0,04 \\
\hline $80-100$ & 90,6 & 29,1 & ॥ & 0,88 & - & - & - & - & - & 0,03 \\
\hline \multicolumn{11}{|c|}{ Гній, 140 т/га (background) } \\
\hline $0-20$ & 117,1 & 45,5 & 5,4 & 2,0 & 0,31 & 6,8 & 8,4 & 12,1 & 27,5 & 0,04 \\
\hline $20-40$ & 109,3 & 40,6 & 5,3 & 1,2 & 0,12 & 5,3 & 6,9 & 11,7 & 24,0 & 0,03 \\
\hline $40-60$ & 108,4 & 40,6 & carbonates & 1,09 & 0,13 & 5,1 & 6,3 & 13,6 & 25,2 & 0,02 \\
\hline $60-80$ & 99,0 & Not determ. & ॥ & 1,00 & - & - & - & - & - & 0,02 \\
\hline $80-100$ & 98,8 & ॥ & ॥ & 0,88 & - & - & - & - & - & 0,02 \\
\hline \multicolumn{11}{|c|}{ Background $+P_{1800}$ (in background) } \\
\hline $0-20$ & 148,2 & 55,1 & 11,7 & 4,8 & 0,26 & 15,2 & 12,2 & 19,2 & 46,9 & 0,3 \\
\hline $20-40$ & 129,3 & 54,5 & 10,7 & 3,8 & 0,14 & 11,1 & 11,6 & 17,0 & 39,9 & 0,2 \\
\hline $40-60$ & 114,2 & 48,1 & carbonates & 1,58 & 0,04 & 7,0 & 4,1 & 16,3 & 27,4 & 0,05 \\
\hline $60-80$ & 106,2 & Not determ. & 》 & 1,38 & - & - & - & - & - & 0,05 \\
\hline $80-100$ & 103,5 & ॥ & 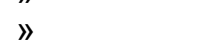 & 1,21 & - & - & - & - & - & 0,04 \\
\hline \multicolumn{11}{|c|}{ Background + $\mathrm{P}_{1800}+2 \mathrm{~N} 2 \mathrm{P} 2 \mathrm{~K}$} \\
\hline $0-20$ & 159,4 & Not determ. & 17,3 & 10,1 & 1,25 & 32,2 & 18,5 & 20,5 & 72,5 & 0,7 \\
\hline $20-40$ & 134,6 & $»$ & 13,6 & 7,1 & 0,65 & 21,9 & 13,0 & 18,8 & 54,4 & 0,2 \\
\hline $40-60$ & 115,9 & » & carbonates & 5,31 & 0,17 & 10,6 & 5,6 & 16,0 & 32,4 & 0,2 \\
\hline $60-80$ & 101,2 & " & 》 & 1,59 & - & - & - & - & - & 0,2 \\
\hline $80-100$ & 94,3 & " & $"$ & 1,45 & - & - & - & - & - & 0,04 \\
\hline
\end{tabular}


The most significant contribution to the formation of agrogenic profile of chernozems on the background of open circulation of phosphorus is made by organic and mineral fertilizers, it is completely transformed the structure of phosphate fund.

By making $140 \mathrm{t} / \mathrm{ha}$ of manure in the third - the fifth rotation (about $8 \mathrm{t} /$ ha on average) it was determined increase of content in the plow layer gross and organic phosphorus and faction of loosely-connected phosphates (from 0.19 on control to $0.31 \mathrm{mg} \mathrm{P} \mathrm{O}_{\text {; }}$ per $100 \mathrm{~g}$ of soil in the manure background). These changes suggest aftereffect of organic fertilizers, because the latter norm was applied 12 years before soil sampling.

On the background of spare application $\mathrm{R}_{\mathrm{m}}$ with a positive balance of phosphorus by 26-year aftereffect (six rotations) practically all indicators of phosphate fund exceeded the relevant fallow data (which is next to the research sites) with the exception of organic phosphates.

In the arable layer gross phosphorus increased by $18 \%$, mobile forms - in 2-3 times the amount of active phosphate and Al-P, which is the closest to reserve power plants - by $78 \%$, and the degree of mobility has increased 5 times. More significantly changed the structure of the fund relative to the phosphate control variant.

Changes of phosphate fund of chernozem typical heavy loamy are observed in soil profiles up to $60 \mathrm{~cm}$ or even deeper. For example, the content of available phosphates specified in saline extract by Olsen method, increased compared with control option at a depth of $80-100 \mathrm{~cm}$ from 0.63 to $1.21 \mathrm{mg} \mathrm{P} \mathrm{O}$; per $100 \mathrm{~g}$ of soil, which is almost 2 times.

Thus, on the background of the reserve application $R_{\text {in }}$ on 26-year of aftereffect it was created acrogenic cultivated phosphate profile, main features of which are the increase in the content of available forms of phosphates and the most available to plants their faction.

Thus, against the reserve making R1800 26-year aftereffect created ahrohennyy cultivated phosphate profile, iconic main features of which is to increase the content of mobile forms of phosphates and mostmore available to plant their faction.

The duration of the fertilizers ' aftereffect (+ $R_{m}$ background option) is more than 25 years, indicating a relatively slow rate of crystallization of residual phosphate fertilizers, which in interaction with soil able to maintain long-term balanced ratio of phosphates of all form of soil phosphates on background of gradual saturation of phosphate capacity and flow of enriched with phosphorus plant residues.

The accumulation of residual soil phosphate increases effective fertility. According to our data, the yield increased by $1-2 \mathrm{c} /$ ha of grain units with an increase in residual phosphate content on $1 \mathrm{mg} \mathrm{P} O \mathrm{O}$ per $100 \mathrm{~g}$ of soil under the same farming practices of growing crops. A common characteristic of soils feature is the variation, smoothing their genetic characteristics that positively affect the productivity of soils with high phosphate levels. This shows the effectiveness of so-called soil reserves of soluble phosphates (Tab. 4). It is calculated using the formula:

The yield of grain, c/ha

Effectiveness of soil reserve $=$

Content of $\mathrm{P}_{2} \mathrm{O}_{5}, \mathrm{mg}$ per $100 \mathrm{~g}$ of soil

4. The effectiveness of soil reserve of soluble phosphates, $\mathrm{c} / \mathrm{mg} \mathrm{P}_{2} \mathrm{O}_{5}$ per $100 \mathrm{~g}$ of soil

\begin{tabular}{|l|l|l|l|l|l|l|}
\hline Agrochemical & $\begin{array}{l}\text { Content } \\
\text { background }\end{array}$ & \multicolumn{6}{|l|}{ The effectiveness of soil phosphate reserve } \\
\cline { 2 - 6 } & $\begin{array}{l}\mathbf{P}_{\mathbf{2}} \mathrm{O}_{5}, \\
\mathbf{m g ~ p e r} \\
\mathbf{1 0 0} \mathbf{~ g} \\
\text { of soil }\end{array}$ & $\begin{array}{l}\text { Grey } \\
\text { forest } \\
\text { soil }\end{array}$ & $\begin{array}{l}\text { chorno- } \\
\text { zem pod- } \\
\text { zolized }\end{array}$ & $\begin{array}{l}\text { Chornozem } \\
\text { typical } \\
\text { (Vinnytska } \\
\text { oblast) }\end{array}$ & $\begin{array}{l}\text { chornozem } \\
\text { typical } \\
\text { (Kharkivska } \\
\text { oblast) }\end{array}$ & $\begin{array}{l}\text { Chornozem } \\
\text { ordinary }\end{array}$ \\
\hline natural & $3,9-6,5$ & 5,2 & 12,1 & 5,7 & 9,3 & 4,8 \\
fertilized & $13,0-16,0$ & 2,8 & 3,4 & 2,6 & 3,1 & 2,9 \\
\hline
\end{tabular}

The effectiveness of soil phosphate reserve on natural background of soil varies strongly, despite the relatively minor differences in the content of phosphates, due to their genetic properties. In fertilized back- 
grounds (with equivalent, but much larger reserve of soluble phosphorus) indicators of payback soil phosphate harvest are quite close. In this case, the soil differences in productivity are smoothed under the influence of residual phosphates of fertilizer.

Thus, according to these data, soil phosphate level affects the effective soil fertility; it was established a close relationship between the accumulation of residual soil phosphate fertilizer and crop harvest that clearly expressed on all types of soils and especially on the chernozem (which is associated with the best value in their available forms of phosphorus and nitrogen). Therefore, the problem of regulating phosphate regime of soil in order to create an optimal level of phosphate plays a special role in dealing effectively improves soil fertility.

The main directions of solving the urgent problems of phosphorus in agriculture Ukraine are, above all, regulation of making of doses of phosphorus fertilizers depending on the payback on soils with different margin residual phosphates and biological features of crops, their ability to absorb phosphate soil and fertilizers. Another direction is the use of local resources to improve soil phosphate treatment, especially against the background of constantly rising prices of manufactured fertilizers and trace amounts of manure due to a sharp decrease in population of all kinds of animals (except for specialized facilities).

Local raw materials that can be used to improve phosphorus balance in agriculture include: phosphate flour from deposits of phosphorites and apatites, pus of different kinds of animals, green manure, crop and root remains, peat, sapropel, and various industrial wastes from the processing of agricultural products.

The most scientifically grounded is application of phosphate flour from local phosphate deposits, which are located in all climatic zones of Ukraine. Long-term studies of many NAAS research institutions it was established efficiency of phosphate flour, prepared and published practical recommendations (2005). It was justified the expediency of application for phosphorite flour predominant soils of Polissya (except sodcarbonate) and Left-bank and Right-bank Forest-Steppe on soils with pH at least 5.5 units, including chernozems.

Return with phosphate flour yield growth (based on aftereffect) on sodpodzolic soils of Polissya is about $90-100 \%$ comparing with superphosphate and weakly podzolized soils and chernozems typical reaches $80-$ $90 \%$. In practice the application of high doses of phosphate (180-240 kg P O per hectare) on 3-4 year of its aftereffect aligned with the same dose of superphosphate.

In sodpodzolic soils of light particle size distribution in Polissya at an important source of phosphorus resupply is green manure. According to O.M. Berdnikov (2016) with different green manures into the soil with phosphorus comes plowing legumes (lupine) 40-60 kg / ha, cereal - 30-50 and cabbage - 40-45 kg / ha.

Application for growing crops of intensive technologies in which the expected collection of primary products in the grinding and uniform distribution across the field side (straw winter, stalks of corn and sunflower), provides a return to the small circular of large amounts of nutrients, including phosphorus.

Studies in NSC ISSAR (S.A. Baliuk and others, 2016) show that on average annually for 2011-2013 phosphorus in the plowing of the by-products is in actual yields, respectively, with straw winter and spring

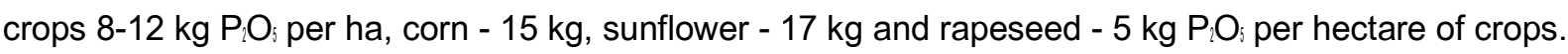

In addition, it was found a significant improvement of the balance of phosphorus sodpodzolic and sandy and sandy loam soil using compost as a part of sapropel, peat and liquid manure and bird droppings. According to I.V. Androshchuk (1995), the contents of available phosphorus in versions with saprope of compost and manure increases by $4-5 \mathrm{mg} \mathrm{P} O \mathrm{O}$; per $100 \mathrm{~g}$ soil.

In addition, it was found a significant improvement of the balance of phosphorus sodpodzolic and sandy and sandy loam soil using compost as a part of sapropel, peat and liquid manure and bird droppings. According to I. Androshchuk (1995), the contents of mobile phosphorus in versions with sapropel compost and manure increases by $4-5 \mathrm{mg} P \mathrm{O}_{\text {i }}$ per $100 \mathrm{~g}$ soil.

Availability of plant with phosphorus can be increased not only additional application of various phosphorus sources. In soils with high acidity of soil solution liming affects significantly on the behavior of soil phosphate. 
Increasing the digestibility of phosphorus in the plants liming due to the intensification of the biological processes of mineralization of soil organic matter due to the increased $\mathrm{pH}$ and form the corresponding mineral compounds, including access to nutrition of plant calcium phosphate.

Indirectly, there are the data of agrochemical survey of soils in the period from 1961 to 1990 , according to which the storage form of phosphorus in sod podzolic soils of Polissya is well ahead of the corresponding figures in other soil-climatic zones (see Table 2), which is due the fertilizer, periodically (every five years) liming of soils. According to studies, the total mineral phosphate with application of phosphate fertilizers increased by $6 \%$ on not liming background and the background of liming - $29 \%$.

An important farming practice, which contributes to more efficient use of phosphorus from soil and fertilizer is to implement a local method of their application. According to A.I. Fateev (2002) coefficient of phosphorus use by local application by rotation is $16.9 \%$ compared to $10.6 \%$ at spreading it to use.

\section{CONCLUSIONS}

Gross reserves of phosphorus in the plow layer of Ukrainian soils are determined by their genetic characteristics and range of 2,5-3,8 t/ha in sodpodzolic loam and sandy soils of Polissya to 20-23 t/ha in chernozem typical heavy loamy and ordinary light loamy of Forest-Steppe and Steppes.

During the intensive use of chemicals (1971-1990) in agriculture has developed positively in the balance of phosphorus: excess phosphorus flow of organic and mineral fertilizers on the removal was $352 \mathrm{~kg} / \mathrm{ha}$ in Polissya, $267 \mathrm{~kg}$ in the Forest-Steppe and $200 \mathrm{~kg}$ in the Steppe zone and overall positive balance of phos-

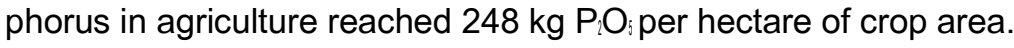

Due to the positive balance, as well as systematic liming of acid soils average content of available phosphorus increased (compared to the first round of the survey, 1964-1970). In Polissya there was from 6.3 to $11.8 \mathrm{mg} \mathrm{P} \mathrm{O}_{\text {; per }} 100 \mathrm{~g}$, in Forest Steppe, respectively, from 8.1 to 10.6 and in Steppe - from 6.8 to $101 \mathrm{mg}$ $\mathrm{P}: \mathrm{O}$.

According to calculations over the 20-year positive balance of phosphorus in soils (mostly in the plow layer) accumulated between 300 and $500 \mathrm{~kg} / \mathrm{ha}$ so-called "residual" phosphates that promote an efficient soil fertility.

Для покращення дефріцитного балансу фоссрору у землеробстві необхідно використовувати місцеві сировинні ресурси, серед яких чільне місце займають поклади фоссроритів, апатитів, торфу, сапропелю, сидерати, а також рослинні залишки сільськогосподарських культур. Важливо впроваджувати такі агротехнічні заходи, як локальне внесення добрив і вапнування кислих ґрунтів, що значною мірою сприяє більш ефрективному використанню фросфатів ґрунту і добрив.

To improve the deficit balance of phosphorus in agriculture need to use local raw materials, including prominent place occupied by deposits of phosphate, apatite, peat, sapropel, green manure, crop residues and crops. It is important to introduce such Agrotech-night events as local fertilizing and liming acid soils that knowledge-chnoyu conducive to more efficient use of soil and phosphate fertilizers.

\section{References}

1. Kovda A.V. Biogeochemistry of soil cover /A.V. Kovda. -M.: Science, 1985. -260 p.

2. Periodic report on the state of soil on agricultural land of Ukraine (based on the results of the 9th round - 2006-2010) of agrochemical land survey. -K., 2015.

3. Lisovy M.V. Computer programs in agrochemical research / M.V. Lisovy, V.M. Nikonenko // Journal of Agricultural Science. Special Issue.2016. —C. 73-890.

4. Barber S.A. Soil Nutrient Bioavailability. Mechanistic Approach. New Jork. USA. 1984.

5. Kudeyarova A.Yu. Use of indicators of phosphate buffering capacity of soils for studying their phosphate regime and substantiation of effective application of phosphorus fertilizers/A.Yu. Kudeyarova // Agrochemistry.1971. № 11. -P. 15-21.

6. Nosko B.S. On the kinetics of sorption of phosphates by soils. B.S. Nosko, I.A. Horolets // Agrochemistry and Soil Science — Is. 50. — K., 1987.—P.3-7. 
7. Androshchuk I.V. Sapropel effect of fertilizers on water-physical properties of sodpodzolic soil, yield and quality of agricultural crops / I.V. Androshchuk, B.S. Nosko // Soil Science and Agrochemistry. 1995. -V. 57-P. 42-45.

8. Scientific bases and practical recommendations on the use of soluble forms of phosphate fertilizers from local fields / Ed. B.S.Nosko. - Kh., 2005. -110 p.

9. Systems of fertilizing crops in agriculture in XXI century / ed. S.A. Baliuk and M.M. Miroshnychenko K.: Alfa, 2016. -392 p.

10. Baliuk S.A. Modern problems of biological degradation of chernozems and ways to preserve their fertility /S.A. Baliuk, B.S. Nosko, Ye.V. Skrylnyk // Journal of Agricultural Science.2015. № 11 . - P. 11-17.

11. Fateev A.I. Local method of fertilizer application. Soil-agrochemical aspects / A.I. Fateev -Kh., 2002. $160 \mathrm{p}$. 